\title{
ALUMINUM HYDROXY-INTERLAYERED MINERALS AND CHEMICAL PROPERTIES OF A SUBTROPICAL BRAZILIAN OXISOL UNDER NO-TILLAGE AND CONVENTIONAL TILLAGE ${ }^{(1)}$
}

\author{
Alberto Vasconcellos Inda ${ }^{(2)}$, José Torrent ${ }^{(3)}$, Vidal Barrón $^{(3)}$ \& Cimélio Bayer ${ }^{(2)}$
}

\begin{abstract}
No tillage systems significantly influence the soil system, but knowledge about the effects on the mineralogy of tropical and subtropical soils is limited. This study evaluated the long-term effects (26 years) of no-tillage (NT) on aluminum hydroxy-interlayered minerals of a subtropical Oxisol in Southern Brazil (Guarapuava, PR), compared to the same soil under conventional tillage (CT). The clay fraction $(<2 \mu \mathrm{m})$ in soil samples of the surface horizons of a field experiment under both management systems was analyzed by X-ray diffraction (XRD) to identify and characterize Al hydroxy-interlayered minerals before and after treatment with sodium citrate to remove intra-layer material. Soil liquid (solution) and solid phases were also characterized. The contents of total organic C, exchangeable cations, $P$, and the values of extractable acidity and cation exchange capacity as well as electrical conductivity and levels of dissolved organic $\mathrm{C}$, basic cations, aluminum, $\mathrm{Si}$, and sulfur in the soil solution were higher in the NT soil. Under both soil management systems, more than $90 \%$ of the total soluble Al was complexed with organic compounds, with similar Al activity. No significant changes were detected by 2:1 clay mineral XRD analyses in terms of extension or intercalation of Al-hydroxy-polymers in the no-tilled in comparison to the conventionally tilled soil. In both soil management systems, $\mathrm{Al}$ and Si activities in the soil solution indicated thermodynamic stability of 2:1 clay minerals with partially occupied by hydroxy-Al, suggesting deceleration in the intercalation process and a tendency of transforming clay minerals from extensive into partial intercalation.
\end{abstract}

Index terms: HIS, HIV, organic carbon, soil management systems, mineral stability.

\footnotetext{
(1) Received for publication on May 2009 and accepted on November 2009.

(2) Professor of Departamento de Solos, Universidade Federal do Rio Grande do Sul - UFRGS. Bento Gonçalves Ave, CEP 97105 400 Porto Alegre (RS). E-mails: alberto.inda@ufrgs.br; cimelio.bayer@ufrgs.br

(3) Professor of Departamento de Ciencias y Recursos Agrícolas y Forestale, Universidad de Córdoba - UCO. Campus de Rabanales, Edif. C-4, Ctra Madrid, km 396, Córdoba, Spain. E-mails: torrent@uco.es; vidal@uco.es
} 


\title{
RESUMO: ARGILOMINERAIS 2:1 COM HIDRÓXI-AL E ATRIBUTOS QUÍMICOS DE UM LATOSSOLO BRUNO SUBTROPICAL SOB SISTEMAS DE PLANTIO DIRETO E CONVENCIONAL
}

\begin{abstract}
O sistema de plantio direto (SPD) representa uma interferência importante no sistema solo, sendo pequeno o conhecimento existente sobre sua influência na mineralogia de solos tropicais e subtropicais. Este estudo foi realizado em experimento de campo e teve por objetivo avaliar o efeito da utilização do SPD, por 26 anos, na intercalação de polímeros de hidróxi-Al nas entrecamadas de argilominerais 2:1 HE de um Latossolo Bruno do Sul do Brasil (Guarapuava, PR), em relação ao mesmo solo cultivado em sistema de preparo convencional $(\mathrm{SPC})$. A fração argila $(<2 \mu \mathrm{m})$ de amostras de solo superficial $(0-0,03 \mathrm{~m})$, coletadas em ambos os sistemas de manejo, foi analisada por difração de raios $X(D R X)$, antes e após tratamento com citrato de sódio visando à identificação e caracterização dos argilominerais 2:1 HE. As características químicas das fases sólida e líquida dos solos também foram avaliadas. O solo em SPD apresentou maiores teores de Corgânico total, cátions trocáveis e de $P$, bem como maior acidez extraível e maior capacidade de troca de cátions. Na fase líquida, o solo do SPD apresentou maiores valores de condutividade elétrica, Corgânico dissolvido, cátions básicos, Al, Si e S na solução do solo. A atividade do Al em solução foi semelhante nos dois sistemas de manejo, com mais de 90 \% da concentração total de Al estando complexado por ligantes orgânicos. A análise dos argilominerais 2:1 por DRX não evidenciou alterações significativas na extensão ou no grau de intercalação de polimeros de hidroxi-Al nas entrecamadas no solo em SPD, em relação ao solo em SPC. A atividade do Al e do Si em solução indicou uma condição de estabilidade para argilominerais 2:1 com entrecamadas parcialmente ocupadas por hidroxi-Al em ambos os sistemas de manejo de solo, o que sugere uma desaceleração no processo de intercalação e uma tendência de transformação dos argilominerais com intercalação extensiva para uma intercalação parcial.
\end{abstract}

Termos de indexação: EHE, VHE, carbono orgânico, sistemas de manejo do solo, estabilidade mineral.

\section{INTRODUCTION}

Soil is a complex open system and constantly evolves as it exchanges energy and matter with neighboring systems (Smeck et al., 1983). Interferences in this system can be observed rapidly in the soil solution, in the medium term in the morphological features and eventually in the mineralogy of the clay fraction, and in the long term as modifications in soil texture. In recent decades, the progressive replacement of conventional tillage (CT) by no-tillage (NT) has significantly interfered with the soil system, and normally resulted in a significantly improved quality of the tropical and subtropical soils in Brazil (Mielniczuk et al., 2003; Bayer et al., 2006).

Long-term research has shown positive effects of NT on the recovery and stabilization of soil structure (Costa et al., 2003), on the reduction of the influence of toxic ions on plants (Salet et al., 1999; Ciotta et al., 2002), increased nutrient availability (Anghinoni, 2007), and the improvement of biotic conditions for plant development (Tótola \& Chaer, 2002). On the other hand, little is known about the influence of NT on the mineralogy of formerly conventionally tilled soils.

Alterations in pedogenic iron oxides were found in an no-tilled Oxisol of the Brazilian Cerrado, mainly in the top soil layer, which mainly consisted of the reordering of these minerals by dissolution and neoformation (Silva Neto et al., 2008). These alterations in the mineralogy of iron oxides were attributed to changes in the pedo-environmental conditions resulting from the implementation of NT, which normally leads to an increase in organic matter content (Ciotta et al., 2002; Costa et al., 2004; Dieckow et al., 2009), an increase in moisture and the residence time of water, in addition to a decrease in soil temperature (Salton \& Mielniczuk, 1995; Costa et al., 2003). Due to the close relationship of these effects with soil and climate variables, such pedoenvironmental changes destabilize the system and a new dynamic equilibrium is established that can also gradually affect the stability of 2:1 clay minerals with interlayered Al hydroxyl (Karathanasis \& Wells, 1989; Azevedo et al., 1996; Officer et al., 2006), frequently found in the clay fraction of soils in the subtropical regions of Brazil (Pötter \& Kämpf, 1981; Curi et al., 1984; Ker \& Resende, 1990; Kämpf et al., 1995; Almeida et al., 2000).

In $\mathrm{X}$ ray diffractometry (XRD), 2:1 clay minerals with interlayered Al hydroxyl (HIV-vermiculite and HIS-smectite) are identified by reflection at approximately $1.4 \mathrm{~nm}$. The contraction after thermal treatments of K-saturated samples and expansion after solvation with ethylene glycol or glycerol (Ker \& 
Resende, 1990; Kämpf et al., 1995; Almeida et al., 2000; Kämpf \& Curi, 2003) depend on the degree of intercalation of $\mathrm{Al}-\mathrm{OH}$ polymers in the interlayers. HIV and HIS clay minerals are considered stable in moderately acidic pedo-environments with low organic matter content (Kämpf \& Curi, 2003). However, changes in the formation conditions, resulting from the implantation of soil conservation management systems, can destabilize/transform these minerals by the partial removal of Al hydroxyl polymers from the interlayers (Karathanasis \& Wells, 1989; Kämpf \& Curi, 2003).

In a laboratory study, Niederbudde \& Rühlicke (1981) raised the $\mathrm{pH}$ of acidic soils (pH between 3.6 and 5.4) with limestone to values $>7.2$ and detected a relative release of $\mathrm{Al}$ hydroxyl polymers from vermiculite interlayers by XRD analysis. Under field conditions, such alterations were not observed in HIS clay minerals after 23 years of application of limestone (40 $\mathrm{Mg} \mathrm{ha}^{-1}$ ) to a subtropical Oxisol (Latossolo Bruno), but the reduction of $\mathrm{Al}$ activity in soil solution indicated a deceleration of the intercalation of $\mathrm{Al}-\mathrm{OH}$ in the interlayers of this clay mineral (Azevedo et al., 1996). In addition to the $\mathrm{pH}$ and ion activity in the solution, the stability of clay minerals with interlayered $\mathrm{Al}$ hydroxyl can be affected by the accumulation of soil organic matter (SOM) in the surface layers of no-tilled soils, due to potential Alcomplexes in the soil solution (Salet et al., 1999; Ciotta et al., 2002). A similar effect was observed in areas of intensive grazing, where the depolymerization of HIV clay minerals was attributed to the $\mathrm{pH}$ increase and factors associated with the concentrated urine and manure deposition (Officer et al., 2006).

The preparation of organo-mineral complexes under controlled conditions has demonstrated the effectiveness of different organic ligands in the depolymerization of HIS and HIV clay minerals (Indraratne et al., 2007; Huang et al., 2007). Studying the incipient podzolization process in inceptisols, Brahy et al. (2000) related the instability of HIS and HIV clay minerals at the soil surface to the $\mathrm{Al}$ depletion after its complexation in the solution by low molecular weight organic acids. This interpretation has also explained the presence of depolymerized smectites and vermiculites in surface horizons with the accumulation of organic matter superimposed on subsurface horizons with the presence of HIV and HIS (Carnicelli et al., 1997; Pai et al., 2004).

The main objective of this study was to evaluate long-term (26 years) effects of NT on the intercalation of Al hydroxyl polymers in the interlayers of $\mathrm{HE} 2: 1$ clay minerals in a subtropical Oxisol.

\section{MATERIALS AND METHODS}

This study was performed in a long-term experiment (26 years) on a Hapludox (Latossolo Bruno Alumínico by the Brazilian Soil Classification System
- Embrapa, 2006), in an area of the Fundação Agrária de Pesquisa Agropecuária (FAPA), in Guarapuava, state of Paraná. The regional climate is $\mathrm{Cfb}$, perudic and mesothermal, with no dry season, average temperature of $16.9^{\circ} \mathrm{C}$, precipitation of $1,956 \mathrm{~mm}$ year ${ }^{1}$ (Fontoura \& Bayer, 2008) and altitude between 900 and $1,200 \mathrm{~m}$ asl. The soils had evolved from basic volcanic rocks of the Triassic period (basalts of the Serra Geral formation).

Prior to the experiment, the soil was used for successive wheat and soybean crops under CT from 1968 to 1978, when the experiment was initiated. The experiment tested different winter and summer management combinations, aside from liming treatments. For this study, only the continuous NT and CT treatments, unlimed from the beginning of the experiment, were sampled. Between 1978 and 1985, a succession of wheat (Triticum aestivum) and soybean (Glycine max) was grown. Thereafter, a crop rotation system was implemented, including the species white oat (Avena sativa L.), wheat, barley (Hordeum spp.), common vetch (Vicia sativa), and radish (Raphanus sativus) in the winter, and soybean and maize (Zea mays) in the summer.

In September 2007, soil samples were collected from the $0-0.03 \mathrm{~m}$ layer of the three experimental replications of each treatment (NT and CT) and a composite sample with a blend of the soil collected from all three experimental replications. The samples were air-dried, harrowed, and sieved through $2 \mathrm{~mm}$ mesh to obtain air-dried fine soil (ADFS). The clay fraction was collected as sediment after ultrasonic dispersion of particles, as described by Inda Junior et al. (2007). Clay fraction in suspension was flocculated with $0.1 \mathrm{~mol} \mathrm{~L}^{-1} \mathrm{HCl}$, washed with a 1:1 alcohol/water solution, and oven-dried at $60^{\circ} \mathrm{C}$.

In the soil samples (ADFS), the total organic $\mathrm{C}$ (TOC) content was determined by dry combustion in a Shimadzu-TOC carbon analyzer $\left(\mathrm{V}_{\mathrm{CSH}}\right.$ model). The $\mathrm{Si}, \mathrm{Al}, \mathrm{Fe}, \mathrm{Ti}, \mathrm{Mn}$, and $\mathrm{P}$ contents were determined after sulfur attack (Embrapa, 1997). Water $\mathrm{pH}$ and $\mathrm{Ca}, \mathrm{Mg}, \mathrm{K}, \mathrm{Al}, \mathrm{H}+\mathrm{Al}$, and $\mathrm{P}$ contents in the exchange complex were determined according to Tedesco et al. (1995). The Fe of all pedogenic Fe oxides (Fed) was extracted with sodium dithionite-citrate-bicarbonate at $80^{\circ} \mathrm{C}$, in two successive extractions (Inda Junior \& Kämpf, 2003). The Fe of the low-crystalline Fe oxides (Feo) was extracted with $0.2 \mathrm{~mol} \mathrm{~L}^{-1}$ ammonium oxalate at pH 3 in the dark (Schwertmann, 1964).

The soil solution was extracted according to the methodology used by Azevedo et al. (1996). To six PVC tubes per management system (diameter $2.2 \mathrm{~cm}$, height $7.5 \mathrm{~cm}$, bottom closed with a $0.45 \mu \mathrm{m}$ millipore filter), $25 \mathrm{~g}$ ADFS and $8 \mathrm{~mL}$ of deionized water were added (by capillary action). The tubes were covered with plastic film to minimize evaporation, and maintained at $25^{\circ} \mathrm{C}$ for $24 \mathrm{~h}$. The solution was extracted by centrifugation at 4,000 rpm for half an hour. The recovered volume was approximately $30 \%$ 
$(2.5 \mathrm{~mL})$ of the total water content added to the sample. Immediately after extraction, the $\mathrm{pH}$ and electric conductivity were determined. Three days later, the dissolved organic $\mathrm{C}$ content of the refrigerated samples was directly determined by the dry combustion method and the $\mathrm{CO}_{2}$ generated was determined by infrared detector, in the Shimadzu C analyzer. The $\mathrm{Ca}, \mathrm{Mg}$, $\mathrm{K}, \mathrm{Na}, \mathrm{Fe}, \mathrm{Al}, \mathrm{Si}, \mathrm{Mn}, \mathrm{P}$, and $\mathrm{S}$ contents were determined by optical emission spectrophotometry (ICP-OES). The speciation and chemical activity of $\mathrm{Al}$ in the soil solution were estimated with the MINTEQ visual computer program (Visual Minteq, 2006).

The X-ray diffractometry (XRD) analysis (Siemens D 5000 Diffractometer, with CoKa radiation and $\mathrm{Fe}$ filter, operated at $40 \mathrm{kV}$ and $25 \mathrm{~mA}$ ) was performed on inclined slides prepared with $60 \mathrm{mg}$ of iron-free clay with sodium dithionite-citrate-bicarbonate. The interlayered material was extracted as described by Kämpf et al. (1995) and Pai et al. (2004). The treatment consisted of heating $\left(100^{\circ} \mathrm{C}\right) 120 \mathrm{mg}$ of clay in $30 \mathrm{~mL}$ in $0.3 \mathrm{~mol} \mathrm{~L}^{-1}$ sodium citrate solution (pH 7.3) for $24 \mathrm{~h}$, renewing the solution every $8 \mathrm{~h}$. Samples treated with or without sodium citrate were saturated with $\mathrm{Mg}\left(0.5 \mathrm{~mol} \mathrm{~L}^{-1} \mathrm{MgCl}_{2}\right)$ and $\mathrm{K}\left(1 \mathrm{~mol} \mathrm{~L}^{-1}\right.$ $\mathrm{KCl})$ to evaluate expansion and contraction, respectively, of $2: 1$ clay minerals. The samples were saturated with $\mathrm{Mg}$ at $25^{\circ} \mathrm{C}$ and subsequently solvated with glycerol (50 $\mathrm{g} \mathrm{L}^{-1}$ in ethanol) by dripping from the inclined slides to drain the excess. The Ksaturated samples were analyzed at $25^{\circ} \mathrm{C}$ and after heating to 110,350 , and $550{ }^{\circ} \mathrm{C}$.

\section{RESULTS AND DISCUSSION}

\section{Chemical properties of the soil solid phase}

The chemical properties related to the soil sorption complex and mineral composition in the $0-0.03 \mathrm{~m}$ layer under both management systems are listed in table 1 . The soil management systems did not affect the $\mathrm{pH}$ or exchangeable $\mathrm{Al}$ content. The increased soil acidity, also demonstrated by the low base and high $\mathrm{Al}$ saturation, was mainly due to the extraction of bases by harvest removal of grains during this long period (26 years) without liming, while nitrate leaching may also have contributed slightly to soil acidification (Vieira et al., 2008).

The total organic carbon content (TOC) in no-tilled soil increased by $50 \%$ in comparison to the soil under $\mathrm{CT}$, which resulted in a higher potential acidity $(\mathrm{H}+\mathrm{Al})$, due to the $-\mathrm{COOH}$ and $-\mathrm{OH}$ groups of organic matter, and cation exchange capacity (CEC). The increase in sum of bases (SB) was related to straw residues on the soil surface under NTS, with subsequent nutrient mineralization and ion retention in the soil CEC. In turn, the higher phosphorus contents were related to the occupation by SOM of sites located on the surface of $\mathrm{Fe}$ and $\mathrm{Al}$ oxides, and by not tilling the soil surface layer under NT. Under CT, plowing and disking incorporate phosphorus into a large soil quantity of the arable layer, exposing high energy surface groups of $\mathrm{Fe}$ and $\mathrm{Al}$ oxides and increasing $\mathrm{P}$ adsorption.

The change of the management system did not affect the content of elements related to the mineral composition of the clay fraction, determined by sulfur attack. The Ki index values below unity ( 0.81 in NT soil and 0.89 in CT soil) indicated a highly weathered soil with predominant gibbsite. The selective dissolution of $\mathrm{Fe}$ oxides suggested dominance of crystalline over low crystalline (Feo/Fed) forms, which is less than $5 \%$ of the total Fe compared to pedogenic Fe oxides (Fed). The decrease of approximately $5 \%$ of the Fed content in NT soil can be a consequence of the reductive and/or complexing dissolution of $\mathrm{Fe}$ oxides, as reported by Silva Neto et al. (2008), in the surface layer of an no-tilled Oxisol (Latossolo Vermelho by the Brazilian Classification System).

Table 1. Chemical characteristics of the solid phase of a subtropical Oxisol under conventional tillage (CT) and no-tillage (NT)

\begin{tabular}{|c|c|c|c|c|c|c|c|c|c|c|c|c|}
\hline \multirow{2}{*}{$\begin{array}{l}\text { Management } \\
\text { system }\end{array}$} & \multirow[b]{2}{*}{$\mathrm{pH}_{\mathrm{H}_{2} \mathrm{O}}$} & \multirow{2}{*}{ TOC } & \multicolumn{7}{|c|}{ Sorptive complex } & \multirow{2}{*}{ V } & \multirow[b]{2}{*}{$\mathbf{m}$} & \multirow{2}{*}{$\mathbf{P}$} \\
\hline & & & $\mathbf{C a}$ & $\mathrm{Mg}$ & $\mathbf{K}$ & Al & SB & $\mathrm{H}+\mathrm{Al}$ & CTC & & & \\
\hline & & $\mathrm{g} \mathrm{kg}^{-1}$ & 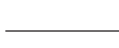 & 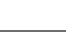 & 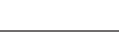 & $-\mathrm{cmol}_{\mathrm{c}} \mathrm{c}$ & $\mathrm{n}^{-3}$ & & - & 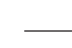 & - & $\mathrm{mg} \mathrm{dm}^{-3}$ \\
\hline CT & 4.3 & 38.2 & 1.3 & 0.2 & 0.33 & 2.3 & 1.8 & 13.7 & 15.6 & 12 & 56 & 2.6 \\
\hline \multirow{4}{*}{ NT } & 4.2 & 57.3 & 2.6 & 0.5 & 0.46 & 2.4 & 3.6 & 17.3 & 20.9 & 17 & 40 & 11.0 \\
\hline & \multicolumn{7}{|c|}{ Sulfur attack } & & & & & \\
\hline & $\overline{\mathrm{P}_{2} \mathrm{O}_{5}}$ & $\mathrm{Fe}_{2} \mathrm{O}_{3}$ & $\mathrm{MnO}$ & \multirow{4}{*}{$\%$} & $\mathrm{TiO}_{2}$ & $\mathrm{Al}_{2} \mathrm{O}_{3}$ & $\overline{\mathrm{SiO}_{2}}$ & $\mathbf{K i}$ & Fed & Feo & Alo & Feo/Fed \\
\hline & & & & & & & & & $\mathrm{g} \mathrm{kg}^{-1}$ & \multicolumn{2}{|c|}{$-\mathrm{mg} \mathrm{kg}^{-1}-$} & \\
\hline $\mathrm{CT}$ & 0.4 & 14.8 & 0.07 & & 2.8 & 24.1 & 11.5 & 0.81 & 102.0 & 3.4 & 5.2 & 0.03 \\
\hline NT & 0.4 & 13.9 & 0.07 & & 2.6 & 23.0 & 12.1 & 0.89 & 97.7 & 3.6 & 5.3 & 0.04 \\
\hline
\end{tabular}

TOC: total organic carbon; SB: sum of bases; CEC: cation exchange capacity; V: base saturation; m: $\mathrm{Al}$ saturation; $\mathrm{Ki}=\mathrm{SiO}_{2} / \mathrm{Al}_{2} \mathrm{O}_{3}$; Fed: iron extracted by sodium dithionite-citrate-bicarbonate; Feo and Alo: iron and aluminum extracted by ammonium oxalate. 


\section{Chemical composition of soil solution}

The composition of the soil solution in the $0-0.03 \mathrm{~m}$ layer under both management systems is presented in table 2. The $\mathrm{pH}$ of the solution was 0.2 units lower in the NT soil than in conventionally tilled soil. The greater electrolyte concentration in the NT soil, as shown by electric conductivity, reflected the increase in basic cation $(\mathrm{Ca}, \mathrm{Mg}, \mathrm{Na}$, and $\mathrm{K})$ contents in solution, following the same tendency observed in the sorption complex. This agrees with results of Ciotta et al. (2002). The organic matter accumulation in the top soil layer under NT contributed to a three-fold increase in the content of dissolved organic carbon (DOC) over the CT soil. DOC can be associated with the significant $\mathrm{Al}$ increase (not found in the sorption complex) and Si in the solution of NT soils (Karathanasis \& Wells, 1989). According to Azevedo et al. (1996), the effect of NT on the soil solution can also be shown in the increase of $\mathrm{S}$ in solution, mainly derived from the mineralization of organic matter.

The chemical speciation of $\mathrm{Al}$ (Table 3 ) showed that most (> $90 \%$ ) of the total soluble $\mathrm{Al}$ concentration in the soil (0 to $0.03 \mathrm{~m}$ layer) is complexed by organic ligands in both soil management systems. A significant difference between the management systems was the greater percentage of concentration related to free $\mathrm{Al}\left(\mathrm{Al}^{3+}\right)$ and to the hydrolyzed species $\left(\mathrm{Al}(\mathrm{OH})_{2}{ }^{+}\right.$and $\left.\mathrm{AlOH}^{2+}\right)$ in the $\mathrm{CT}$ soil, whereas under NT the percentages of $\mathrm{Al}$ associated with phosphorus and $\mathrm{Si}$ was greater (Table 2). Al activity was low in both soil management systems $\left(10^{-7}\right)$, compared to the activities normally found in soils from Southern Brazil $\left(10^{-6}\right)$ (Salet et al., 1999), which can be related to the increased organic matter contents in soils under both soil management systems. Although $\mathrm{Al}$ activity was greater in NT than CT soil, the difference was not significant when the total $\mathrm{Al}$ contents in solution were considered $\left(0.22 \mathrm{mg} \mathrm{L}^{-1}\right.$ under CT and $0.53 \mathrm{mg} \mathrm{L}^{-1}$ under NT). According to Salet et al. (1999), the decreased $\mathrm{Al}$ activity in soil solution under NT results from the increased DOC contents and the greater ionic strength of the solution, influencing the formation of Al-organic ligand complexes and increasing the interaction between the ions in solution, respectively.

\section{Al hydroxyl 2:1 clay minerals}

The mineral compositions of the total clay fraction in soils under both management systems were similar (diffractogram not shown), consistent with research in Oxisols in Southern Brazil (Pötter \& Kämpf, 1981; Curi et al., 1984; Ker \& Resende, 1990; Kämpf et al., 1995). The intensity of the XRD reflections evidenced

Table 2. Composition of solution of a subtropical Oxisol under conventional tillage (CT) and no-tillage (NT)

\begin{tabular}{|c|c|c|c|c|c|c|c|c|c|c|c|}
\hline Management system & $\mathrm{pH}_{\mathrm{H}_{2} \mathrm{O}}$ & EC & DOC & $\mathbf{C a}$ & Mg & $\mathrm{Na}$ & $\mathbf{K}$ & $\mathrm{Al}$ & Si & $\mathbf{S}$ & $\mathbf{P}$ \\
\hline & \multicolumn{3}{|c|}{$\mu \mathrm{S} \mathrm{cm}^{-1}$} & \multicolumn{8}{|c|}{$-\mathrm{mg} \mathrm{L}^{-1}$} \\
\hline $\mathrm{CT}$ & 4.9 & 265 & 30.9 & 10.99 & 6.15 & 0.84 & 12.34 & 0.22 & 4.60 & 2.00 & 0.07 \\
\hline $\mathrm{NT}$ & 4.7 & 555 & 86.7 & 30.94 & 13.89 & 3.58 & 22.00 & 0.53 & 7.60 & 7.40 & 0.44 \\
\hline
\end{tabular}

EC: electrical conductivity; DOC: dissolved organic carbon.

Table 3. Aluminum speciation and activity in the solution of a subtropical Oxisol under conventional tillage (CT) and no-tillage (NT), at $\mathrm{pH}=4.9$ and $\mathrm{Al}=0.22 \mathrm{mg} \mathrm{L}^{-1}$ under $\mathrm{CT}$; and $\mathrm{pH}=$ 4.7 and $\mathrm{Al}=0.53 \mathrm{mg} \mathrm{L}^{-1}$ under NT

\begin{tabular}{|c|c|c|}
\hline \multirow{2}{*}{$\begin{array}{c}\text { Species and } \\
\text { chemical activity }\end{array}$} & \multicolumn{2}{|c|}{ Management system } \\
\hline & CT & NT \\
\hline Org. Al-L & 92.75 & 93.50 \\
\hline $\mathrm{Al}(\mathrm{OH})_{2}^{+}$ & 0.75 & 0.20 \\
\hline $\mathrm{Al}(\mathrm{OH})_{3}(\mathrm{aq})$ & 0.02 & 0.00 \\
\hline $\mathrm{Al}^{3+}$ & 3.19 & 2.50 \\
\hline $\mathrm{AlH}_{3} \mathrm{SiO}_{4}{ }^{2+}$ & 0.14 & 0.11 \\
\hline $\mathrm{AlHPO}_{4}^{+}$ & 1.03 & 2.74 \\
\hline $\mathrm{AlOH}^{2+}$ & 2.12 & 0.95 \\
\hline Activity & $1.86 \times 10^{-7}$ & $2.90 \times 10^{-7}$ \\
\hline
\end{tabular}

gibbsite $(0.48 \mathrm{~nm})$ as predominant mineral in the soil, followed by kaolinite $(0.72$ and $0.36 \mathrm{~nm})$ and a less intense reflection at $1.40 \mathrm{~nm}$ indicated the $2: 1$ minerals.

In the XRD of the clay samples not treated with sodium citrate, the intensity of the reflection at $1.4 \mathrm{~nm}$ was reduced and a gradual asymmetric enlargement at high ${ }^{0} 2 \theta$ angles after saturation and thermal treatments (Figure 1a, b; Table 4). According to Kämpf \& Curi (2003), this behavior indicates extensive occupation of the interlayers by $\mathrm{Al}$ hydroxyl, which impedes the complete contraction of $2: 1$ clay minerals at $1.00 \mathrm{~nm}$. The expected modifications in the ability of clay minerals with interlayered $\mathrm{Al}$ hydroxyl to contract (reduction of spacing $d$ ) due to the change of soil management system was not confirmed by XRD in the K-saturated samples heated to $350{ }^{\circ} \mathrm{C}$. When heated to $550{ }^{\circ} \mathrm{C}$, the contraction of clay minerals in NT soil $(d=1.159 \mathrm{~nm})$ was slightly greater in comparison to the conventionally tilled soil 
$(d=1.175 \mathrm{~nm})$. These results, however, are not significant when compared to the effect of organic ligands on depolymerization of HIS and HIV in laboratory experiments (Indraratne et al., 2007; Huang et al., 2007). The diffraction pattern of Mgsaturated clays did not show significant changes after solvation with glycerol for 12 and 26 days (Figure 1a,b; Table 4). This behavior indicated the presence of HIV (Bigham et al., 2002), although it should be remembered that an extensive occupation of interlayers inhibits the expansion of minerals, hindering the distinction between HIV and HIS (Kämpf et al., 1995).

The composition of interlayer materials in the analyzed 2:1 clay minerals was considered aluminous, as these clay samples were previously treated with two extractions with sodium dithionite-citratebicarbonate for the removal of pedogenic iron oxides. Therefore, if the interlayer materials consisted of $\mathrm{Fe}$ $\mathrm{OH}$, the expansion and contraction procedures would have been more effective.

In the XRD of samples treated with sodium citrate for the removal of $\mathrm{Al}$ hydroxyl polymers, $\mathrm{K}$ saturation and the thermal treatments produced reductions of spacing $d$ compared to those of samples not treated with sodium citrate (Figure 2a,b; Table 4). This was mainly observed in samples heated to 350 and $550^{\circ} \mathrm{C}$, although there was no formation of reflections at $1.00 \mathrm{~nm}$, indicating that the removal was still ineffective. In these samples, the diffraction pattern of Mg-saturated clay was also only slightly changed by solvation with glycerol. Although not very significant, the expansion of the interlayers after the treatments with $\mathrm{Mg}$ and glycerol always resulted in greater $d$ spacing in the samples of NT soil.

Therefore, 26 years of NT did not result in significant changes in the mineralogy of Al hydroxyl interlayered 2:1 clay minerals in this acidic Oxisol with high organic matter content. Possibly, the greater contents of organic matter resulted in a (a)

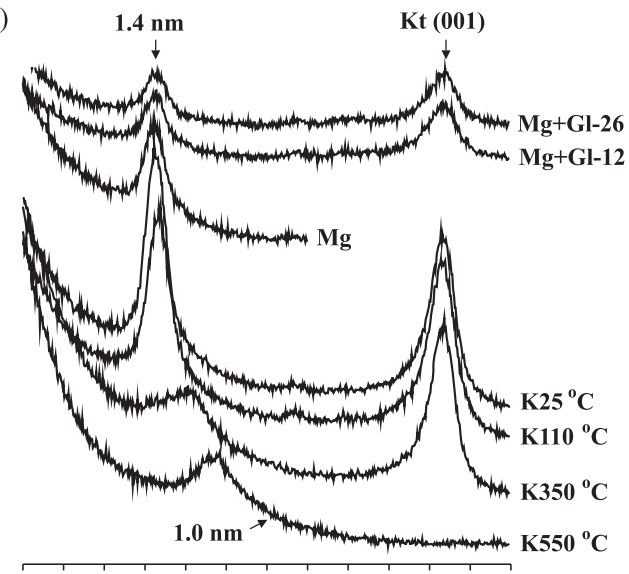

(b)

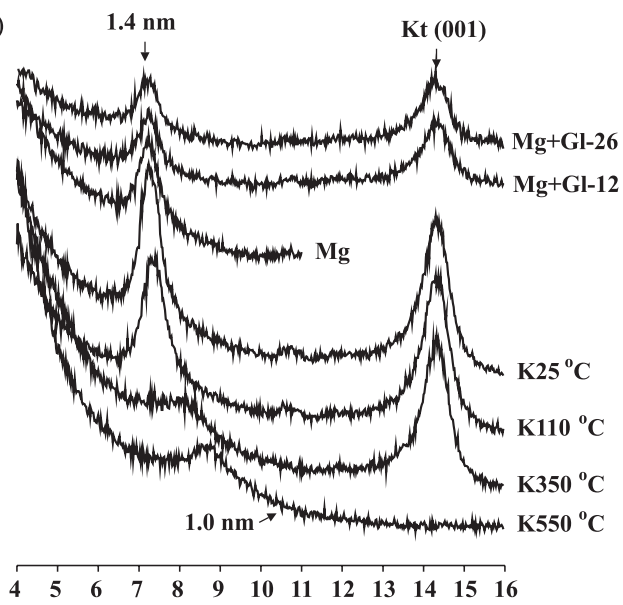

Figure 1. X-ray diffractograms of the clay fraction of soil under conventional tillage (a) and notillage (b) without the treatment with sodium citrate. Mg: saturation by magnesium; Mg+Gl$n^{\circ}$ : saturation by magnesium followed by solvation with glycerol for 12 and 26 days; $\mathrm{Kn}^{\circ}$ ${ }^{\circ} \mathrm{C}$ : saturation by potassium and respective thermal treatments; Kt: kaolinite. Scale in degrees $\left({ }^{\circ} 2 \Theta\right)$.

Table 4. Spacing $d$ of 2:1 minerals with interlayered aluminum hydroxyl in saturation and heating treatments

\begin{tabular}{|c|c|c|c|c|c|c|c|}
\hline \multirow{2}{*}{ Management sistem } & \multicolumn{7}{|c|}{ Spacing $d(\mathrm{~nm})$} \\
\hline & $\mathrm{K} 25^{\circ} \mathrm{C}$ & $\mathrm{K} 110{ }^{\circ} \mathrm{C}$ & $\mathrm{K} 350^{\circ} \mathrm{C}$ & $\mathrm{K} 550^{\circ} \mathrm{C}$ & Mg & $\mathrm{Mg}+\mathrm{Gl}-12$ & $\mathrm{Mg}+\mathrm{Gl}-26$ \\
\hline $\mathrm{CT}$ & 1.406 & 1.394 & $\begin{array}{c}1.267 \\
(1.400 \text { to } 1.162)^{1)}\end{array}$ & $\begin{array}{c}1.175 \\
\text { (1.323 to } 1.079)\end{array}$ & 1.406 & 1.410 & 1.410 \\
\hline \multirow[t]{3}{*}{ NT } & 1.402 & 1.391 & $\begin{array}{c}1.267 \\
(1.400 \text { to } 1.151)\end{array}$ & $\begin{array}{c}1.159 \\
(1.344 \text { to } 1.044)\end{array}$ & 1.414 & 1.414 & 1.422 \\
\hline & \multicolumn{7}{|c|}{ With treatment with sodium citrate } \\
\hline & $\mathrm{K} 25^{\circ} \mathrm{C}$ & $\mathrm{K} 110^{\circ} \mathrm{C}$ & $\mathrm{K} 350{ }^{\circ} \mathrm{C}$ & $\mathrm{K550}{ }^{\circ} \mathrm{C}$ & Mg & $\mathrm{Mg}+\mathrm{Gl}-12$ & $\mathrm{Mg}+\mathrm{Gl}-26$ \\
\hline $\mathrm{CT}$ & 1.402 & 1.387 & (1.400 to 1.116$)$ & (1.299 to 0.956$)$ & 1.414 & 1.418 & 1.418 \\
\hline NT & 1.395 & 1.380 & (1.400 to 1.044$)$ & (1.290 to 0.955$)$ & 1.426 & 1.430 & 1.436 \\
\hline
\end{tabular}

(1) Numbers in brackets represent the spacing $d$ for the extreme ${ }^{0} 2 \theta$ angles of the reflections. 

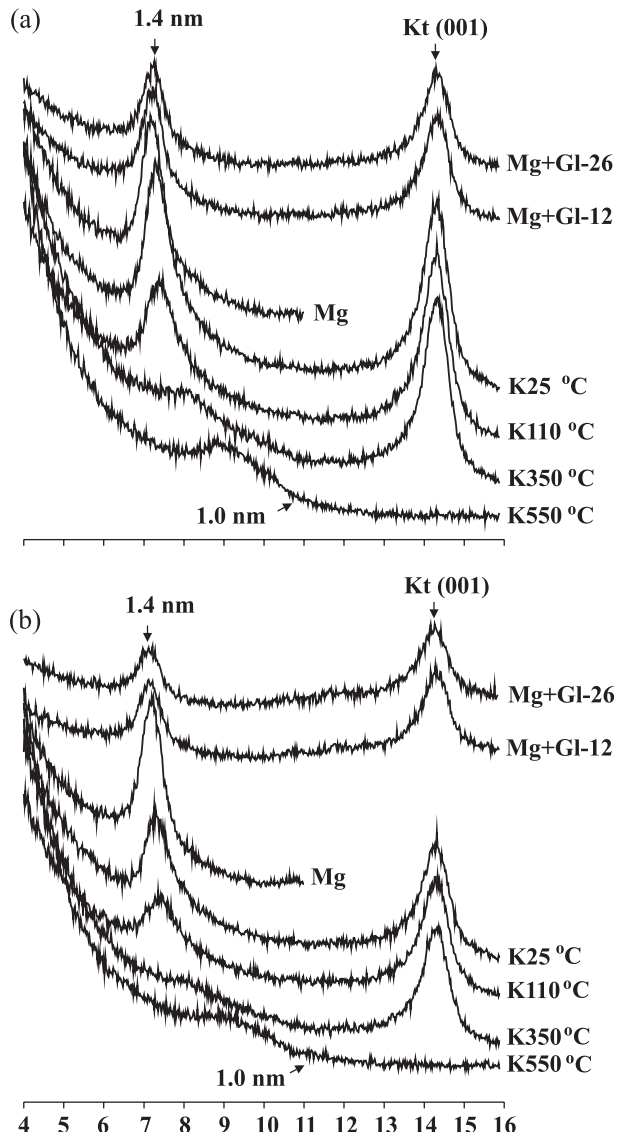

Figure 2. X-ray diffractograms of the clay fraction of soil under conventional tillage (a) and notillage (b) after treatment with sodium citrate. Mg: saturation by magnesium; $\mathrm{Mg}+\mathrm{Gl}-\mathrm{n}^{\circ}$ saturation by magnesium followed by solvation with glycerol for 12 and 26 days; $\mathrm{Kn}^{\circ}{ }^{\circ} \mathrm{C}$ : saturation by potassium and respective thermal treatments; Kt: kaolinite. Scale in degrees $\left({ }^{\circ} 2 \Theta\right)$. effects on the mineralogy of tropical and subtropical Brazilian soils.

Since the change in soil management system did not result in significant changes in the mineralogy of Al hydroxyl interlayered 2:1 clay minerals, the possible tendencies of mineral changes determined by the alterations in the management system are identified in a stability diagram ( $\mathrm{pH}-1 / 3 \mathrm{pAl}$ versus $\left.\mathrm{pH}_{4} \mathrm{SiO}_{4}\right)$ (Figure 3). The stability lines were selected according to Azevedo et al. (1996), representing 2:1 clay minerals with extensive intercalation (HIS-E and HIV-E) and partial intercalation by $\mathrm{Al}$ hydroxyl (HIS-P and HIV$\mathrm{P})$, with kaolinite, gibbsite, quartz, and amorphous silica.

In the diagram, the points of the $\mathrm{CT}$ and $\mathrm{NT}$ were between the lines for quartz and amorphous silica, indicating that the formation of the latter is not favored. The point of the CT indicated stability of HIS-P and supersaturation of HIV-P, whereas the point of the NT showed supersaturation of both minerals (HIS-P and HIV-P), in spite of the dominance of gibbsite and kaolinite minerals in this soil. A similar tendency was found by Azevedo et al. (1996) in the 0-0.2 m layer of a subtropical Oxisol; after 23 years of liming (40 $\mathrm{Mg} \mathrm{ha}^{-1}$ ), there was a significant deviation compared to the treatment without limestone addition, where kaolinite remained stable.

The stable condition for 2:1 clay minerals with interlayers partially occupied by Al hydroxyl is related to the low activity of $\mathrm{Al}$ and the high activity of silica in the $0-0.03 \mathrm{~m}$ layer under both management systems, and results from the increased organic matter contents in this soil, due to the low temperatures (annual average $t=16.9{ }^{\circ} \mathrm{C}$ ) and high contribution of plant residues from the crop rotation system. This condition indicates a deceleration in the intercalation and a tendency to transform clay

tendency to reduce the degree of intercalation of $\mathrm{Al}$ hydroxyl layers in soil under NT. However, the kinetic effect of only organic matter on the environmental conditions of temperature and moisture was not sufficient to induce more significant changes in the 26 year period. In this sense, it is noteworthy that the increase of $\mathrm{pH}$ values by liming, along with the increased organic matter contents, can contribute to higher kinetics of the reactions involved in this destabilization of HE 2:1 clay minerals in no-tilled soils. Under NT, limestone is applied to the soil surface, which results in a $\mathrm{pH}$ increase in this soil layer compared to soil under CT, where limestone is incorporated uniformly in the arable soil layer. In this situation, $\mathrm{pH}$ and organic matter would induce a reduction of $\mathrm{Al}$ content and activity in solution, which would cause changes in the stability of interlayered Al hydroxyl polymers. This possible combined effect of $\mathrm{pH}$ (liming) and organic matter will need to be assessed in future studies in long-term experiments to deepen the understanding of possible management

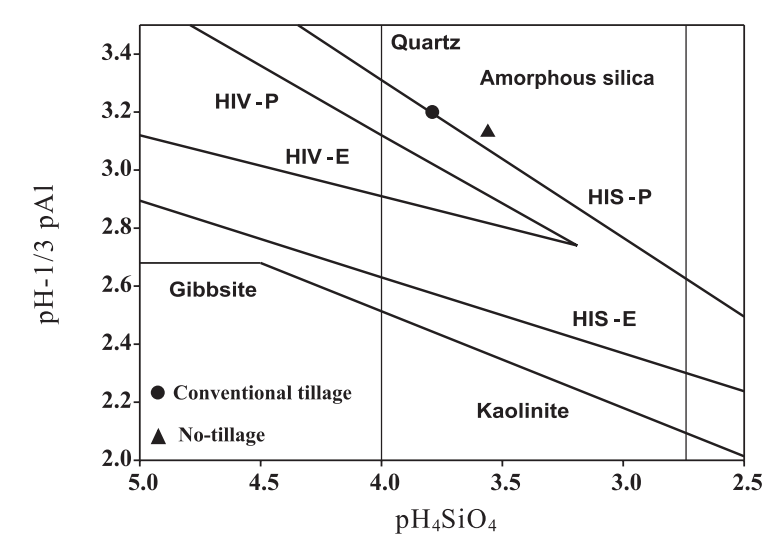

Figure 3. Stability diagram representing the soil solution composition in relation to the stability lines of minerals. HIS-smectite with interlayered aluminum hydroxyl and HIVvermiculite with interlayered aluminum hydroxyl, with partial (P) and extensive (E) intercalation. 
minerals with extensive intercalation (HIS-E or HIV E) into those with partial intercalation (HIS-P or HIVP). According to Karathanasis et al. (1989), this does not necessarily lead to a reversal of the weathering sequence in this soil, but shows that the soil system has been altered in such a way that the precursor or intermediate minerals (2:1 clay minerals with partial intercalation with $\mathrm{Al}$ hydroxyl) may be becoming stable in the new pedo-environment.

\section{CONCLUSIONS}

1. The 26-year use of a no-tillage after a conventional tillage system resulted in chemical changes of the subtropical oxisol, evidenced by the increase of total organic C, exchangeable cations, extractable acidity, phosphorus contents, and cation exchange capacity. In the soil solution, the no-tillage system increased the electrical conductivity, dissolved organic $\mathrm{C}$, basic cations, $\mathrm{Al}$, silica, and sulfur contents .

2. Al activity was similar in the two soil management systems and more than $90 \%$ of the total concentration of this element was complexed by organic ligands. Of the remaining $\mathrm{Al}$, free and hydrolyzed $\mathrm{Al}$ forms predominated in the soil under conventional tillage, whereas under no-till, the forms associated with silica and phosphorus predominated.

3. Analysis of 2:1 clay minerals by $\mathrm{X}$ ray diffraction did not show significant changes in the degree of intercalation of Al hydroxyl polymers in the interlayers of the soil under a no-tillage system in comparison with a conventional tillage system. However, the activity of $\mathrm{Al}$ and of $\mathrm{Si}$ in solution indicated stability for 2:1 clay minerals with interlayers partially occupied by Al hydroxyl in both soil management systems, which suggests a deceleration in the intercalation and a tendency of transformation of clay minerals with extensive intercalation into partial intercalation.

\section{ACKNOWLEDGEMENTS}

The authors whish to thank the Cooperativa Agrária Mista Entre Rios (S.A.) and the Fundação Agrária de Pesquisa Agropecuária for assuming the responsibility and granting permission for this longterm experiment, the Conselho Nacional de Desenvolvimento Científico e Tecnológico (CNPq) for financial support (Edital Universal-2007, process 481389/2007-5) and for the research grant of C. Bayer; the Coordenação de Aperfeiçoamento de Pessoal Docente (CAPES) for the postdoctoral fellowship of the first author; and the Departamento de Ciencias y Recursos Agrícolas y Forestale, Universidad de Córdoba- Spain.

\section{LITERATURE CITED}

ALMEIDA, J.A.; MAÇANEIRO, K.C. \& KLAMT, E. Mineralogia da fração argila de solos vermelhos com horizontes superficiais brunados do Planalto de Lages (SC). R. Bras. Ci. Solo, 24:815-828, 2000.

ANGHINONI, I. Fertilidade do solo e seu manejo no sistema plantio direto. In: NOVAIS, R.F.; ALVAREZ V., V.H.; BARROS, N.F.; FONTES, R.L.F.; CANTARUTTI, R.B. \& NEVES, J.C.L., orgs. Fertilidade do solo. Viçosa, MG, Sociedade Brasileira de Ciência do Solo, 2007. v.1. p.873928.

AZEVEDO, A.C.; KÄMPF, N. \& BOHNEN, H. Alterações na dinâmica evolutiva de Latossolo Bruno pela calagem. R. Bras. Ci. Solo, 20:191-198, 1996.

BAYER, C.; MARTIN NETO, L.; MIELNICZUK, J.; PAVINATO, A. \& DIECKOW, J. Carbon sequestration in two Brazilian Cerrado soils under no-till. Soil Till. Res., 86:237-245, 2006.

BIGHAM, J.M.; FITZPATRICK, R.W. \& SCHULZE, D. Iron oxides. In: DIXON, J.B. \& SCHULZE, D.G. Soil mineralogy with environmental applications. Madison, Soil Science Society of America, 2002. p.323-366. (Book Series, 7)

BRAHY, V.; TITEUX, H. \& DELVAUX, B. Incipient podzolization and weathering caused by complexation in a Forest Cambisol on loess as revealed by a soil solution study. J. Soil Sci., 51:475-484, 2000.

CARNICELLI, S.; MIRABELLA, A.; CECCHINI, G. \& SANESI, G. Weathering of chlorite to a low-charge expandable mineral in a Spodosol on the Apennine Mountains, Italy. Clays Clay Miner., 45:28-41, 1997.

CIOTTA, M.N.; BAYER, C.; ERNANI, P.R.; FONTOURA, S.M.V.; ALBUQUERQUE, J.A. \& WOBETO, C. Acidificação de um Latossolo sob plantio direto. R. Bras. Ci. Solo, 26:1055-1064, 2002.

COSTA, F.S.; ALBUQUERQUE, J.A.; BAYER, C.; FONTOURA, S.M.V. \& WOBETO, C. Propriedades físicas de um Latossolo Bruno afetadas pelos sistemas plantio direto e preparo convencional. R. Bras. Ci. Solo, 27:527535,2003

COSTA, F.S.; BAYER, C.; ALBUQUERQUE, J.A. \& FONTOURA, S.M.V. Aumento de matéria orgânica num Latossolo Bruno em plantio direto. Ci. Rural, 34:587-589, 2004.

CURI, N.; KÄMPF, N. \& RESENDE, M. Mineralogia, química, morfologia e geomorfologia de solos originados de rochas efusivas das Encostas Superior e Inferior do Nordeste, no Rio Grande do Sul. R. Bras. Ci. Solo, 8:269-276, 1984.

DIECKOW, J.; BAYER, C.; CONCEIÇÃO, P.C.; ZANATTA, J.A.; MARTIN-NETO, L.; MILORI, D.B.M.; SALTON, J.C.; MACEDO, M.M.; MIELNICZUK, J. \& HERNANI, L.C. Land use, tillage, texture and organic matter stock and composition in tropical and subtropical Brazilian soils. Eur. J. Soil Sci., 60:240-249, 2009. 
EMPRESA BRASILEIRA DE PESQUISA AGROPECUÁRIA . EMBRAPA. Centro Nacional de Pesquisa de solos. Manual de métodos de análise de solo. 2.ed. Rio de Janeiro, 1997. 212p. (Documentos, 1).

EMPRESA BRASILEIRA DE PESQUISA AGROPECUÁRIA EMBRAPA. Centro Nacional de Pesquisa de Solos. Sistema brasileiro de classificação de solos. Rio de Janeiro, Embrapa Solos, 2006. 412p.

FOnTOURA, S.M.V. \& BAYER, C. Trinta anos do experimento de manejo de solo, Guarapuava, PR. Guarapuava, Fundação Agrária de Pesquisa Agropecuária, 2008. 56p.

HUANG, L.; TAN, W.; LIU, F.; HU, H. \& HUANG, Q. Composition and transformation of $1.4 \mathrm{~nm}$ minerals in cutan and matrix of Alfisols in Central China. J. Soils Sediments, 7:240-246, 2007.

INDA JUNIOR, A.V.; BAYER, C.; CONCEIÇÃO, P.C.; BOENI, M.; SALTON, J.C. \& TONIN, A.T. Variáveis relacionadas à estabilidade de complexos organo-minerais em solos tropicais e subtropicais brasileiros. Ci. Rural, 37:1301-1307, 2007.

INDA JUNIOR, A.V. \& KÄMPF, N. Avaliação de procedimentos de extração dos óxidos de ferro pedogênicos com ditionitocitrato-bicarbonato de sódio. R. Bras. Ci. Solo, 27:1139$1147,2003$.

INDRARATNE, S.P.; GOH, T.B. \& SHINDO, H. Sorption of organic compounds by hydroxy-interlayered clays through chelation and humification processes. Geoderma, 139:314$320,2007$.

KÄMPF, N. \& CURI, N. Argilominerais em solos brasileiros. In: CURI, N.; MARQUES, J.J.; GUILHERME, L.R.G.; LIMA, J.M.; LOPES, A.S. \& ALVAREZ V., V.H., eds. Tópicos em ciência do solo. Viçosa, MG, Sociedade Brasileira de Ciência do Solo, 2003. v.3. p.1-54.

KÄMPF, N.; AZEVEDO, A.C. \& COSTA JR., M.I. Estrutura básica de argilominerais 2:1 com hidróxi-Al entrecamadas em Latossolo Bruno do Rio Grande do Sul. R. Bras. Ci. Solo, 19:185-190, 1995.

KARATHANASIS, A.D. \& WELLS, K.L. A comparison of mineral weathering trends between two management systems on a catena of loess-derived soils. Soil Sci. Soc. Am. J., 53:582-588, 1989.

KER, J.C. \& RESENDE, M. Caracterização química e mineralogical de Solos Brunos subtropicais do Brasil. R. Bras. Ci. Solo, 14:215-225, 1990.

MIELNICZUK, J.; BAYER, C.; VEZZANI, F.M.; LOVATO, T.; FERNANDES, F.F. \& DEBARBA, L. Manejo de solos e culturas e sua relação com os estoques de carbono e nitrogênio do solo. CURI, N.; MARQUES, J.J.; GUILHERME, L.R.G.; LIMA, J.M.; LOPES, A.S. \& ALVAREZ V., V.H., eds. Tópicos em ciência do solo. Viçosa, MG, Sociedade Brasileira de Ciência do Solo, 2003. v.3. p.209-248.
NIEDERBUDDE, E.A. \& RÜHLICKE, G. Umwandlung von Al-Chloriten durch Kalkung. Z. Pflanzenernähr. Düng. Bodenkd, 144:127-135, 1981.

OFFICER, S.J.; TILLMAN, R.W.; PALMER, A.S. \& WHITTON, J.S. Variability of clay mineralogy in two New Zealand steep-land topsoils under pasture. Geoderma, 132:427440, 2006 .

PAI, C.W.; WANG, M.K.; KING, H.B.; C.Y. CHIU, C.Y. \& HWONG, J.L. Hydroxy-interlayred minerals of forest soils in A-Li Mountain, Taiwan. Geoderma, 123:154-255, 2004.

PÖTTER, R.O. \& KÄMPF, N. Argilo-minerais e óxidos de ferro em Cambissolos e Latossolos sob regime climático térmico údico no Rio Grande do Sul. R. Bras. Ci. Solo, 5:153-159, 1981.

SALET, R.; ANGHINONI, I. \& KOCHHANN, R.A. Atividade do alumínio na solução do solo do sistema plantio direto. R. Ci. Unicruz, 1:9-13, 1999.

SALTON, J.C. \& MIELNICZUK, J. Relações entre sistemas de preparo, temperatura e umidade de um Podzólico Vermelho-Escuro de Eldorado do Sul (RS). R. Bras. Ci. Solo, 19:313-319, 1995.

SCHWERTMANN, U. Differenzierung der Eisenoxide des Bodens durch Extraktion mit Ammoniumoxalat-Lösung. Z. Pflanzenernähr. Düng. Bodenkd, 105:194-202, 1964.

SILVA NETO, L.F.; INDA, A.V.; BAYER, C.; DICK, D.P. \& TONIN, A.T. Óxidos de ferro em Latossolos tropical e subtropical brasileiros em plantio direto. R. Bras. Ci. Solo, 32:1873-1881, 2008.

SMECK, N.E.; RUNGE, E.C.A. \& MACKINTOSH, E.E. Dynamics and genetic modelling of soil systems. In: SMECK, N.E. \& HALL, G.F. Pedogenesis and soil taxonomy: I. Concepts and Interactions. Amsterdam, Elsevier Science Publishers, 1983. 358p.

TEDESCO, M.J. Análise de solo, plantas e outros minerais. Porto Alegre, Universidade Federal do Rio Grande do Sul, 1995. 174p.

TÓTOLA, M.R. \& CHAER, G.M. Microrganismos e processos microbiológicos como indicadores da qualidade do solo. In: ALVAREZ V., V.H.; SCHAEFER, C.E.G.R.; BARROS, N.F.; MELLO, J.W.V. \& COSTA, L.M., eds. Tópicos em ciência do solo. Viçosa, MG, Sociedade Brasileira de Ciência do Solo, 2002. v.2. p. 195-276.

VIEIRA, F. C. B.; BAYER, C.; MIELNICZUK, J.; ZANATTA, J. A. \& BISSANI, C. A. Long-term acidification of a Brazilian Acrisol as affected by no till cropping systems and nitrogen fertilizer. Aust. J. Soil Res., 46:17-26, 2008.

VISUAL MINTEQ, 2006. Free version, Version 2.51. KTH, Department of Land and Water Resources Engineering (www.kth.se), Sweden. 
